\title{
Mixed Allocation Method for Carbon Emission Initial Allowance in Port Industry
}

\author{
Yiying Zhou ${ }^{1}$, Yuanming Jia ${ }^{1}$, Weitong Guo ${ }^{1}$, Jing $\mathrm{Li}^{1 *}$ \\ ${ }^{1}$ China Waterborne Transport Research Institute, Beijing, 100088, P.R. China
}

\begin{abstract}
Targeting issues in initial allocation of carbon emission allowance in port industry, this study puts forth a mixed allocation method that uses the baseline method for handling production allowance and the historical intensity method for auxiliary production allowance. This study clarifies the organizational boundary and operational boundary using this method, analyzes related factors, and provides the computational formulas. In the instance analysis, the specific calculation process of applying this method to specialized container terminal, specialized dry bulk terminal and general terminal, as well as the value method of basic data and correlation coefficient are given. Compared with the single use of historical intensity method or baseline method for allocation of allowances, although the operation of the mixed allocation method is relatively complicated, it not only considers the historical emission basis of the emission control enterprises, but also achieves a fairer and more reasonable performance by setting the baseline intensity of the loading and unloading production links. This research will help drive port companies to enter the carbon emissions trading markets as soon as possible, playing a promotive role in catalysing sustainable development of port companies.
\end{abstract}

\section{Introduction}

\subsection{Background}

In 2011, a pilot program for carbon emission trading was officially launched in China, with seven provinces/municipalities including Beijing and Shanghai becoming the first to execute the pilot program. In 2017 , the preparation for a nationwide unified carbon emission trading market was officially launched, and the national systemic trading rules were published for the first time at the end of 2020. Since the carbon trading pilot program was launched, all pilot regions have focused on highenergy-consuming industries such as electrical power and iron \&steel industries, less involving transportation. In various pilot systems, Shanghai has included aviation and ports ${ }^{[1]}$ while Shenzhen and Beijing have included buses, taxis, rail transit vehicles and stations ${ }^{[2]}$, however, not many companies have participated. During "the 14th Five-year Plan", as one of important steps to implement the objective of new peak carbon dioxide emissions and the vision of carbon neutral, carbon emission trading will transform from pilots to the whole country, from single industries to multiple industries, and as one of key fields to deal with climate changes, the transportation industry will be bound to face the topic. As a large and powerful port country, China's port throughput has always ranked first in the world and maintained rapid growth in recent years. Catalysing port companies to join the carbon emission trading system as soon as possible is of great significance to sustainably grow, transform and upgrade ports.

Allocating carbon emission allowance is an important step in carbon emission trading playing the fundamental role. Here, the rules for allocation of initial allowance shall maximize the efficiency of the allocation process and the fairness of the allocated results ${ }^{[3]}$. At present the lack of technical support for initial allowance allocation is one of vital reasons that lots of port companies cannot join the trading system ${ }^{[4]}$. Therefore, by drawing on practical experiences in carbon emission trading in pilot regions and other industries at home, and considering the features of energy consumption of the port industry, putting forth an allocation method of the carbon emission initial allowance fit for the port industry is of importance to promote port companies to participate in the carbon emission trading.

\subsection{Basic Method}

The carbon emission initial allowance allocation includes compensated allocation and uncompensated allocation which was universally used in the early days of implementing the emission trading system. In practice, the uncompensated allocation generally uses the historical intensity method and the baseline method.

(1)Historical intensity method

The emission allowance of an emission-controlling company is determined based on its historical carbon dioxide emission data and the current year's actual

\footnotetext{
* Corresponding author: lijing@wti.ac.cn
} 
capacity, with the computational formula shown in Formula (1). The historical emission intensity is:

$$
A=B \times F \times Q \quad(1)
$$

Where, $A$ is the carbon emission initial allowance, $B$ is the historical emission intensity, which shall be the mean emission intensity of 3 or 4 years before the allocation year; $F$ is the emission-controlling factor, which should be determined in a unified way by the competent authority, with the value of $0 \sim 1$ in general; $Q$ is the current year's output or capacity of the company.

(2)Baseline method

The emission allowance is checked and ratified based on the industry's reference carbon emission intensity and the current year's actual capacity of the emissioncontrolling company, with the computational formula shown in Formula (2).

$$
A=B M \times F \times Q
$$

Where, $A$ is the carbon emission initial allowance, $B M$ is the reference value of the emission intensity, which should be determined and evaluated in a unified way by the competent authority; $F$ is the emissioncontrolling factor; $Q$ is the current year's output or capacity of the company.

\section{Methodology Research}

\subsection{Carbon Emission Calculation Boundary}

The organizational boundary for carbon emission calculation is defined as the handling production systems which are directly used by port companies for handling production and the auxiliary production systems which are directly used serving the handling production ${ }^{[5]}$. To be noted, production processes outsourced to a third party shall also be included in the boundary, while the carbon emissions generated by anchored ships from using shore power and thermal insulation of reefer containers are excluded.

The operational boundary for carbon emission calculation is defined as direct emissions generated from fossil fuel burning, and indirect emissions generated from purchased power and heat.

\subsection{Influencing Factors}

Comprehensively considering division of energy-use systems, handling technology, energy-consuming equipment and the status quo of the energy consumption statistic work of port companies in China, the influencing factors for the mixed allocation method include four categories: basic information, production data, energy consumption data and calculative coefficients, as shown in Table 1

Table 1. Influencing factors

\begin{tabular}{|c|c|c|}
\hline & & $\begin{array}{l}\text { belt conveyors in each handling } \\
\text { process in the dry bulk cargo } \\
\text { terminals etc. }\end{array}$ \\
\hline \multirow{3}{*}{$\begin{array}{l}\text { produc } \\
\text { tion } \\
\text { data }\end{array}$} & throughput & $\begin{array}{l}\text { the port throughput assigned in } \\
\text { the current year and that in } \\
\text { previous } 1-3 \text { years }\end{array}$ \\
\hline & $\begin{array}{l}\text { equipment } \\
\text { operation } \\
\text { coefficient }\end{array}$ & $\begin{array}{l}\text { the ratio between the } \\
\text { operational quantity of each } \\
\text { main energy consumption } \\
\text { equipment and the throughput }\end{array}$ \\
\hline & $\begin{array}{l}\text { production } \\
\text { proportional } \\
\text { ity } \\
\text { coefficient }\end{array}$ & $\begin{array}{l}\text { the proportions on direct } \\
\text { loading and direct delivery, } \\
\text { water-water transit, hold } \\
\text { cleaning operation and terminal } \\
\text { loading/unloading ships }\end{array}$ \\
\hline \multirow{2}{*}{$\begin{array}{l}\text { energy } \\
- \\
\text { consu } \\
\text { mption } \\
\text { data }\end{array}$} & $\begin{array}{c}\text { energy } \\
\text { consumption } \\
\text { for handling } \\
\text { production }\end{array}$ & $\begin{array}{l}\text { the quantity of physical } \\
\text { materials for energy } \\
\text { consumption for main energy } \\
\text { consumption equipment }\end{array}$ \\
\hline & $\begin{array}{l}\text { energy } \\
\text { consumption } \\
\text { for auxiliary } \\
\text { production }\end{array}$ & $\begin{array}{l}\text { the quantity of physical } \\
\text { materials for energy } \\
\text { consumption for auxiliary } \\
\text { production }\end{array}$ \\
\hline \multirow{3}{*}{\multicolumn{2}{|c|}{$\begin{array}{l}\text { carbon emission } \\
\text { calculative coefficient }\end{array}$}} & $\begin{array}{l}\text { coefficient for converting each } \\
\text { energy resource to standard coal }\end{array}$ \\
\hline & & $\begin{array}{l}\text { fuel lower calorific value, fuel } \\
\text { carbon content per unit calorific } \\
\text { value and oxidation rate of } \\
\text { fossil fuels }\end{array}$ \\
\hline & & $\begin{array}{l}\text { carbon emission factor of } \\
\text { indirect emission fuels }\end{array}$ \\
\hline
\end{tabular}

\begin{tabular}{|c|c|l|}
\hline \multicolumn{2}{|c|}{ Influencing Factors } & \\
\hline \multirow{3}{*}{$\begin{array}{c}\text { basic } \\
\text { data }\end{array}$} & equipment & $\begin{array}{l}\text { type and specification of main } \\
\text { energy consumption equipment } \\
\text { in each process of handling } \\
\text { production }\end{array}$ \\
\cline { 2 - 3 } & plane layout & the conveying distances of the \\
\hline
\end{tabular}

\subsection{Mixed Allocation Method}

The mixed allocation method is to use different methods to allocate initial allowance for the handling production processes and auxiliary production processes based on their different energy-consumption features. See Equation (3) for the calculation formula.

$$
E=E U+E A
$$

Where,

$E$ - the carbon emission initial allowance for each company $\left(\mathrm{t}-\mathrm{CO}_{2}\right)$.

$E U$ - the carbon emission initial allowance for the handling production process $\left(\mathrm{t}-\mathrm{CO}_{2}\right)$.

$E A$ - the carbon emission initial allowance for the auxiliary production process $\left(\mathrm{t}-\mathrm{CO}_{2}\right)$.

\subsubsection{Method for the Handling Production}

The handling production include four processes: shoreside operation, horizontal transportation, storage area operation and truck-side operation ${ }^{[5]}$ for which the initial allowance are all calculated with the baseline method. The reference value of the carbon emission intensity at each process can be determined with the following two ways.

(1) The carbon emission intensity sequence method

The reference value is determined by sequencing the carbon emission intensity of a handling production process of main port enterprises in the region, with the computational formula shown in Equation (4). 


$$
E U=\sum_{i=1}^{4} C_{i, x \%} \times T
$$

Where,

$E U$ - the allowance for the handling production process $\left(\mathrm{t}-\mathrm{CO}_{2}\right)$.

$C_{i, x \%}$ - the $x^{\text {th }}$ value at sequence $C_{i}$ in order of carbon emission intensity of main port companies' handling production process $i\left(\mathrm{t}-\mathrm{CO}_{2} / 10^{4} \mathrm{t}\right.$ or $\left.\mathrm{t}-\mathrm{CO}_{2} / 10^{4} \mathrm{TEU}\right)$.

$T$ - the throughput ( $\mathrm{t}$ or TEU).

\section{(2) Standard estimation method}

The carbon emission reference value of each production process is directly given in accordance with relevant industrial standards, with the computational formula shown in Equation (5).

$$
E U=\sum_{i=1}^{n} \sum_{j=1}^{m} q_{i j} \times \omega \times \eta \times \mu \times T
$$

Where,

$E U$ - the allowance for the handling production process $\left(\mathrm{t}-\mathrm{CO}_{2}\right)$.

$q_{i j}$ - the energy consumption intensity of the $j^{\text {th }}$ kind of equipment used in the $i^{\text {th }}$ handling production process, and the unit will be determined in accordance with the detailed provisions of the selected standard, generally including $\mathrm{kWh} / \mathrm{t}, \mathrm{kg} / \mathrm{t}, \mathrm{kWh} / \mathrm{t} \bullet \mathrm{m}$ etc.

$\omega$ - the conversion coefficient of equipment operational quantity. It is a coefficient for the conversion between the unit operational quantity intensity of each main energy consumption equipment and the throughput, and its unit varies with the unit of the energy consumption intensity.

$\eta$ - the emission reduction coefficient (\%). It is the ratio between the determined value of energy consumption by a handling equipment and the value of energy consumption specified in the standard which is determined by the competent authority itself for the purpose of encouraging companies to take actions to reduce carbon emissions

$\mu$ - the fuel carbon emission factor. It is the carbon emission quantity per unit energy consumption quantity of each kind of fuel, with the unit related to the kind of the fuel.

$T$ - the throughput (t).

\subsubsection{Method for the Auxiliary Productions}

The auxiliary production processes generally include vehicles and ships operating in port, machine repair and maintenance, production office buildings, water supply and drainage, environmental protection facilities $\operatorname{etc}^{[6]}$.For all kinds of terminals, the initial allowance for each auxiliary production process is allocated with the historical intensity method, with the computational formula shown in Equation (6). Especially, though the site lighting and passenger transport service are usually included in the handling production processes, they are included in the auxiliary production processes in this study considering their energy consumption quantity are closely tied to some objective conditions, such as the area of the storage yard and the passenger hall and the historical intensity method is fitter for them.

$$
E A=\sum_{i=1}^{3}\left(C h_{i} \times \frac{T_{j}}{\sum_{i=1}^{3} T_{j}}\right)
$$

Where,

$E A$ - the allowance for the auxiliary production process $\left(\mathrm{t}-\mathrm{CO}_{2}\right)$.

$C h_{i}$ - the carbon emission intensity of the auxiliary production in the $i$ years before the calculative period ( $\mathrm{t}$ $\mathrm{CO}_{2} / 10^{4} \mathrm{t}$ or $\left.\mathrm{t}-\mathrm{CO}_{2} / 10^{4} \mathrm{TEU}\right)$.

$T_{j}$ - The annual throughput in the $j$ years before the calculative period $(\mathrm{t})$.

\section{Method Applications}

\subsection{Scenario Description}

It is assumed that 9 port companies are eligible and will join the carbon emission trading market in region $\mathrm{A}$, including 3 specialized container terminals, 4 specialized dry bulk cargo terminals and 2 universal terminals. On the basis of the energy statistic data of main port companies in region $\mathrm{A}$, the mixed allocation method is used to do the initial allocation in the given scenario.

\subsection{Allowance Calculation}

It is relatively simple to use carbon emission intensity sequence method and the historical intensity method, and the details will not be given. The process to use the standard estimation method is described as below:

1) Identify the reference handling procedure and main energy consumption equipment at terminals for different kinds of cargoes. In this case, main energy consumption equipment in each production process will be selected from conventional equipment in conventional handling procedure, and equipment operational coefficients will be set by fully considering the actual production conditions of main port companies in the region.

2) Select appropriate threshold or level standard on energy consumption of handling equipment and set the emission reduction coefficient to get the energy consumption intensity for main energy consumption equipment. Since no unified energy consumption threshold standard is established for the operational processes in port production in China, in this case, the energy consumption intensity will be generally referred to JTS 150-2007 Specification for Energy Conservation Design of Port and Waterway Engineering ${ }^{[7]}$. Taking into account that Specification for Energy Conservation Design of Port and Waterway Engineering was set in earlier years, in which the unit energy consumption threshold for equipment may be high; in this case, the emission reduction coefficient is uniformly taken as $90 \%$.

3) In accordance with the selected standard, the reference values of relevant parameters in the region are set one by one, for instance, the plane layout parameters, 
the equipment operational coefficient and the production proportional coefficient. Finally, the conversion coefficient of equipment operational quantity is determined.

4) Calculate the carbon emission reference value for each production process with defined formulas.

\subsubsection{Specialized container terminals}

Main energy consumption equipment in each production process are identified based on the conventional process for handling productions at specialized container terminals, and the conversion coefficient of operational quantity is given for each equipment, as shown in Table 2. Here, the terminal loading/unloading ship proportion is set as $1: 1$, and the direct loading and direct delivery proportion is $10 \%$.

Table 2. Main energy consumption equipment in handling production processes at specialized container terminals

\begin{tabular}{|c|c|c|}
\hline $\begin{array}{c}\text { Handling } \\
\text { production } \\
\text { process }\end{array}$ & $\begin{array}{c}\text { Main energy } \\
\text { consumption } \\
\text { equipment }\end{array}$ & $\begin{array}{c}\text { Conversion } \\
\text { coefficient of } \\
\text { equipment } \\
\text { operational } \\
\text { quantity }\end{array}$ \\
\hline $\begin{array}{c}\text { Shore-side } \\
\text { handling }\end{array}$ & $\begin{array}{c}\text { Quayside container } \\
\text { crane }\end{array}$ & 1.0 \\
\hline $\begin{array}{c}\text { Horizontal } \\
\text { transport }\end{array}$ & $\begin{array}{c}\text { Container traction } \\
\text { semitrailer }\end{array}$ & 0.9 \\
\hline \multirow{3}{*}{$\begin{array}{c}\text { Storage } \\
\text { area }\end{array}$} & E-RTG & 2.6 \\
\cline { 2 - 3 } operation & Empty container stacker & 0.5 \\
\cline { 2 - 3 } & Container reach stacker & 0.2 \\
\cline { 2 - 3 } & Loaded container & 0.3 \\
\cline { 2 - 3 } forklift & Empty container forklift & 0.1 \\
\hline
\end{tabular}

Based on Equation (5), the formula to compute the initial allowance for handling production at the specialized container terminals is:

$$
E U_{c}=54.5004 \times T
$$

Where,

$E U_{c}$ - the allowance for the handling production process at the specialized container terminal $\left(\mathrm{t}-\mathrm{CO}_{2}\right)$.

$T$ - the annual throughput $\left(10^{4} \mathrm{TEU}\right)$.

\subsubsection{Specialized dry bulk cargo terminals}

Main energy consumption equipment ${ }^{[8]}$ in each production process are identified based on the conventional process for handling productions at specialized dry bulk cargo terminals, and the conversion coefficient of operational quantity is given for each equipment, as shown in Table 3. Here, the terminal loading/unloading ship proportion is set as $1: 1$, the direct loading and direct delivery proportion is 0 and the hold cleaning operational quantity is $10 \%$ of the ship unloading operational quantity. In calculation, the length is set as $1000 \mathrm{~m}$ for the belt conveyor in the ship loading/unloading process and $500 \mathrm{~m}$ for the belt conveyor in the truck handling process.
Table 3. Main energy consumption equipment in handling production processes at specialized dry bulk cargo terminals

\begin{tabular}{|c|c|c|}
\hline $\begin{array}{c}\text { Handling } \\
\text { production } \\
\text { process }\end{array}$ & $\begin{array}{c}\text { Main energy } \\
\text { consumption } \\
\text { equipment }\end{array}$ & $\begin{array}{c}\text { Conversion } \\
\text { coefficient of } \\
\text { equipment } \\
\text { operational } \\
\text { quantity. }\end{array}$ \\
\hline \multirow{2}{*}{$\begin{array}{c}\text { Shore-side } \\
\text { handling }\end{array}$} & $\begin{array}{c}\text { Mobile ship loader } \\
\text { Bridge grab ship }\end{array}$ & 0.5 \\
\cline { 2 - 3 } unloader & $\begin{array}{c}\text { Trimming } \\
\text { bulldozer (for hold } \\
\text { cleaning) }\end{array}$ & 0.5 \\
\hline $\begin{array}{c}\text { Horizontal } \\
\text { transport }\end{array}$ & $\begin{array}{c}\text { Belt conveyor } \\
\text { Storage area } \\
\text { operation }\end{array}$ & $\begin{array}{c}\text { Bucket-wheel } \\
\text { stacker reclaimer }\end{array}$ \\
\hline $\begin{array}{c}\text { Truck } \\
\text { handling } \\
\text { operation }\end{array}$ & Truck loader & 1.0 \\
\cline { 2 - 3 } & Screw unloader & 2.0 \\
\hline
\end{tabular}

Based on Equation (5), the formula to compute the initial allowance for handling production at the specialized dry bulk cargo terminals is:

$$
E U_{b}=8.8598 \times T
$$

Where,

$E U_{b}$ - the allowance for the handling production process at the specialized dry bulk cargo terminal ( $t$ $\mathrm{CO}_{2}$ ).

$$
T \text { - the corporate annual throughput }\left(10^{4} \mathrm{t}\right) .
$$

\subsubsection{Universal terminals}

The universal terminals include the universal bulk cargo terminals and the universal general cargo terminal. Their main energy consumption equipment in each production process are identified based on the conventional process for handling productions at specialized dry bulk cargo terminals, and the conversion coefficient of operational quantity is given for each equipment, as shown in Tables 4 and 5. Here, the terminal loading/unloading ship proportion is set as $1: 1$, the direct loading and direct delivery proportion is $50 \%$ and the hold cleaning operational quantity is $10 \%$ of the ship unloading operational quantity.

\begin{tabular}{|c|c|c|}
\hline $\begin{array}{c}\text { Handling } \\
\text { production } \\
\text { step }\end{array}$ & $\begin{array}{c}\text { Main energy } \\
\text { consumption } \\
\text { equipment }\end{array}$ & $\begin{array}{l}\text { Conversion } \\
\text { coefficient of } \\
\text { equipment } \\
\text { operational } \\
\text { quantity. }\end{array}$ \\
\hline \multirow{3}{*}{$\begin{array}{l}\text { Shore-side } \\
\text { handling }\end{array}$} & 10t/16t gantry crane & 0.5 \\
\hline & $25 \mathrm{t} / 40 \mathrm{t}$ gantry crane & 0.5 \\
\hline & $\begin{array}{l}\text { Single-bucket loader } \\
\text { (for hold cleaning) }\end{array}$ & 0.05 \\
\hline $\begin{array}{l}\text { Horizontal } \\
\text { transport }\end{array}$ & Traction trailer & 1.0 \\
\hline $\begin{array}{c}\text { Storage area } \\
\text { operation }\end{array}$ & Single-bucket loader & 1.0 \\
\hline
\end{tabular}

Table 4. Main energy consumption equipment in handling production processes at universal bulk cargo terminals 
Table 5. Main energy consumption equipment in handling production processes at universal general cargo terminals

\begin{tabular}{|c|c|c|}
\hline $\begin{array}{c}\text { Handling } \\
\text { production } \\
\text { process }\end{array}$ & $\begin{array}{c}\text { Main energy } \\
\text { consumption } \\
\text { equipment }\end{array}$ & $\begin{array}{c}\text { Conversion } \\
\text { coefficient of } \\
\text { equipment } \\
\text { operational } \\
\text { quantity. }\end{array}$ \\
\hline $\begin{array}{c}\text { Shore-side } \\
\text { handling }\end{array}$ & $10 \mathrm{t} / 16 \mathrm{t}$ gantry crane & 0.5 \\
\cline { 2 - 3 } & $25 \mathrm{t} / 40 \mathrm{t}$ gantry crane & 0.5 \\
\hline $\begin{array}{c}\text { Horizontal } \\
\text { transport }\end{array}$ & Dump truck & 1.0 \\
\hline $\begin{array}{c}\text { Storage area } \\
\text { operation }\end{array}$ & Rubber-tired crane & 0.7 \\
\cline { 2 - 3 } & Forklift & 0.3 \\
\hline
\end{tabular}

The initial allowance for handling productions at the universal bulk cargo terminals and the universal general cargo terminals can be calculated with Equation (9) and (10) respectively.

$$
E U_{g b}=6.4651 \times T
$$

Where,

$E U_{g b}$ - the allowance for the handling production process at the universal bulk cargo terminal $\left(\mathrm{t}-\mathrm{CO}_{2}\right)$.

$T$ - the corporate annual throughput $\left(10^{4} \mathrm{t}\right)$.

$$
E U_{g}=7.7327 \times T
$$

Where,

$E U_{g}$ - the allowance for the handling production process at the universal general cargo terminal $\left(\mathrm{t}-\mathrm{CO}_{2}\right)$.

$T$ - the corporate annual throughput $\left(10^{4} \mathrm{t}\right)$.

\subsection{Result Analysis}

The carbon emission intensity sequencing (here, $\mathrm{x}$ is 50 ) and the standard estimation method are respectively used to calculate the carbon emission initial allowance for the handling production processes of the 9 companies, while the historical intensity method is used to calculate the carbon emission initial allowance for their auxiliary production. To verify the results from the mixed allocation method, the results calculated with the historical intensity method will be used as control, as shown in Table 6 . The difference ratio in initial allowance between these 3 methods (the ratio between the difference value of the results of Methods 1 and 2 and the bigger value of them) are shown in Figs. $1 \sim 3$ respectively.

Table 6. Results calculated

\begin{tabular}{|c|c|c|c|}
\hline $\begin{array}{c}\text { compa } \\
\text { ny }\end{array}$ & $\begin{array}{c}\text { The carbon } \\
\text { emission } \\
\text { intensity }\end{array}$ & $\begin{array}{c}\text { Standard } \\
\text { estimation } \\
\text { method }\end{array}$ & $\begin{array}{c}\text { Historical } \\
\text { intensity } \\
\text { method }\end{array}$ \\
\hline c.Co1 & 107223.34 & 60569.06 & 102420.15 \\
\hline c.Co2 & 10295.89 & 6154.68 & 11532.82 \\
\hline c.Co3 & 20351.50 & 11373.09 & 9157.55 \\
\hline b.Co1 & 17913.85 & 18399.77 & 14927.53 \\
\hline b.Co2 & 1411.98 & 1448.71 & 1088.48 \\
\hline b.Co3 & 2384.61 & 2450.65 & 1069.79 \\
\hline b.Co4 & 834.51 & 855.12 & 866.67 \\
\hline
\end{tabular}

\begin{tabular}{|l|c|c|c|}
\hline g.Co1 & 5417.78 & 6172.14 & 5233.80 \\
\hline g.Co2 & 7640.57 & 10419.28 & 3531.32 \\
\hline
\end{tabular}

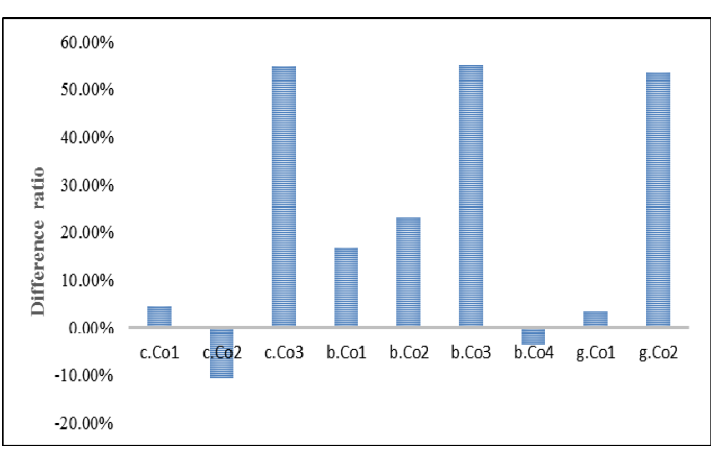

Fig. 1. The difference ratio of results from the carbon emission intensity sequencing and the historical intensity method

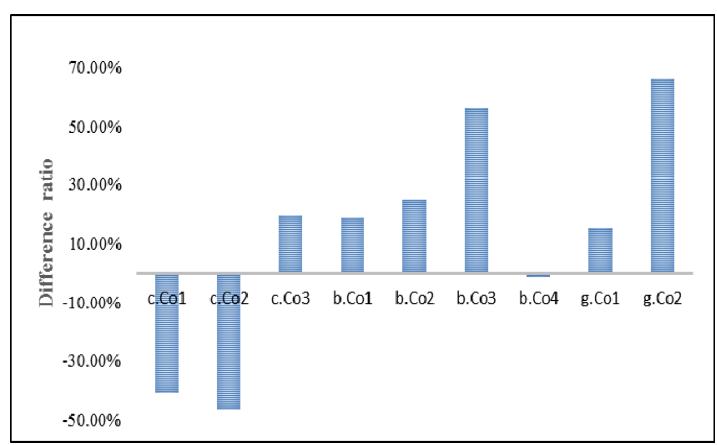

Fig. 2. The difference ratio of results from the standard estimation method and the historical intensity method

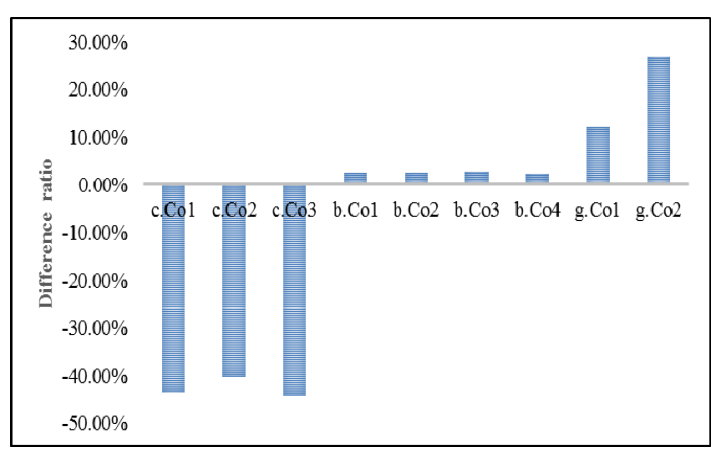

Fig. 3. The difference ratio of results from the carbon emission intensity sequencing method and the standard estimation method

These calculated results are analyzed that:

(1) With different allocation methods, the carbon emission initial allowance available to companies varies, and so does the allocation method the most favorable to them. On these 9 companies, the largest difference ratio of the basic allowance obtained with 3 methods is $66.11 \%$. The mixed allocation method is more favorable to companies with better energy structure and high level of energy efficiency; on the contrary, the historical intensity method is mode favorable to those with poor energy structure and low level of energy efficiency.

(2) The allowance difference obtained from these 3 methods varies significantly. The difference between results allocated with the standard estimation method and the historical intensity method is the largest, with the mean difference ratio of $32.19 \%$. Among them, the 
container terminals enjoy the highest difference ratio, possibly because: 1) in the standard estimation method, the set value of the operational coefficients of such handling equipment as E-RTG, empty container stacker, reach stacker and forklift is lower, and shall be adjusted based on the actual production in the region; 2) the handling production process of the container terminals in the region is relatively backward, so the energy consumption level of the handling equipment falls greatly behind the requirements in the standard.

(3) There are pros and cons in the carbon emission intensity sequencing and the standard estimation method. The carbon emission intensity sequencing requires port companies to provide detailed energy statistic data by steps and by energy-consumption types, which involves high basic statistic requirements and complicate computation. However, the reference values obtained are more accurate, more matching the actual conditions of emission-controlling companies. For the standard estimation method, the calculation is pretty complicate in the initial use, and once the value of all coefficients is determined, it is easy for later use. However, since the method requires the industry to establish rational standards on energy consumption thresholds or level of handling equipment, currently the estimation is rough and the results are low in accuracy. In the actual operation, it is required to adjust various parameters involved in the method, to obtain the computational formula for the allocation methods that are scientific, fair and meet the need of the competent industrial authorities. The acknowledgements should be typed in 9-point Times, without title.

\section{Conclusion}

This paper proposes a mixed allocation method for the initial carbon emission quota in the port industry. This method takes into account the fact that the loading and unloading production processes of port enterprises are relatively consistent, but the auxiliary production processes are quite different, so that the initial allowance is calculated with the baseline method for the handling production and with the historical intensity method for the auxiliary production. Relative to single use of the historical intensity method or the baseline method, the mixed allocation method, although complex in operation, is fairer and more reasonable because it not only considers the historical emission basis of emissioncontrolling companies, but also plays a certain role in promoting companies' emission reduction by setting the reference intensity for the handling production processes. Overall, the mixed allocation method proposed in this paper is a scientific, fair and feasible carbon emission allowance allocation method that better matches the characteristics of China's port industry energy consumption statistics at present.

\section{Acknowledgments}

This work was supported by ministry of finance basic scientific research business fee project.

\section{References}

1. SH/MRV-010-2012, The Method for Accounting and Reporting of Industrial Greenhouse Gas Emissions of Transport Stations in Shanghai [S].

2. Beijing Municipal Ecological and Environmental Bureau. Guidance to Accounting and Reporting of Carbon Dioxide Emission of Carbon Emission Organizations in Beijing [Z]. 2020-04-08.

3. X B.Pan. The Allowance Allocation Regime for Carbon Emission Trading - Analysis from the Perspectives of the Science of Law and Economics. Tianjin: Nankai University Press, 2017.

4. J T. Wang, Q S. Huang, X M. Ma. Status Quo and Overlook of Transportation Participation in Domestic Carbon Trading in China. China Energy. 38,32-37 (2016)

5. NDRC. Guidance to Accounting Methods and Reporting of Greenhouse Gas Emissions of land Transportation Companies (Interim), 2015.

6. GB/T 21339-2020, Energy Consumption Statistic and Analysis Methods in Ports.

7. JTS 150-2007, Specification for Energy Conservation Design of Port and Waterway Engineering.

8. J. Li, Y Y. Zhou. Research on Certification Method of Greenhouse Gas Emission Reduction in Dry Bulk Cargo Terminal Horizontal Transportation Optimization Project, 2020 IOP Conf. Ser.: Earth Environ. Sci. 571012088. 